\title{
Leon van der Wilk
}

Functie/organisatie: groepscontroller bij Parnassia Groep Sport: tennis

Opvallendste prestatie: "Drie jaar geleden stond ik in de finale van een mixtoernooi met tennispartner tegenover mijn zoon van zeventien en een vriendin. We wonnen de derde set met een tiebreak van 9-7. Een thriller."

\section{Waarom tennis?}

“Jarenlang was tennis na voetbal mijn tweede sport, maar rond mijn zestiende kroop het van lieverlee naar de eerste plaats. Al ben ik nog jaren blijven voetballen, en zaalvoetbal heb ik ook nog achttien jaar gedaan. Nu is het alleen nog tennis, zo'n drie keer in de week."

2. Wat is er zo leuk aan?

“Ik ben een echte dubbelaar en dan het liefst mixed dubbel. In het dubbelspel kun je met techniek en tactiek de overwinning behalen, zo slim spelen dat je wint, terwijl je niet eens de betere hoeft te zijn. Niet hard tegen die bal rammen, maar goed met elkaar communiceren, afspreken waar je gaat staan. Maar het plezier gaat boven prestaties. Qua niveau noem ik mezelf een goede recreant."

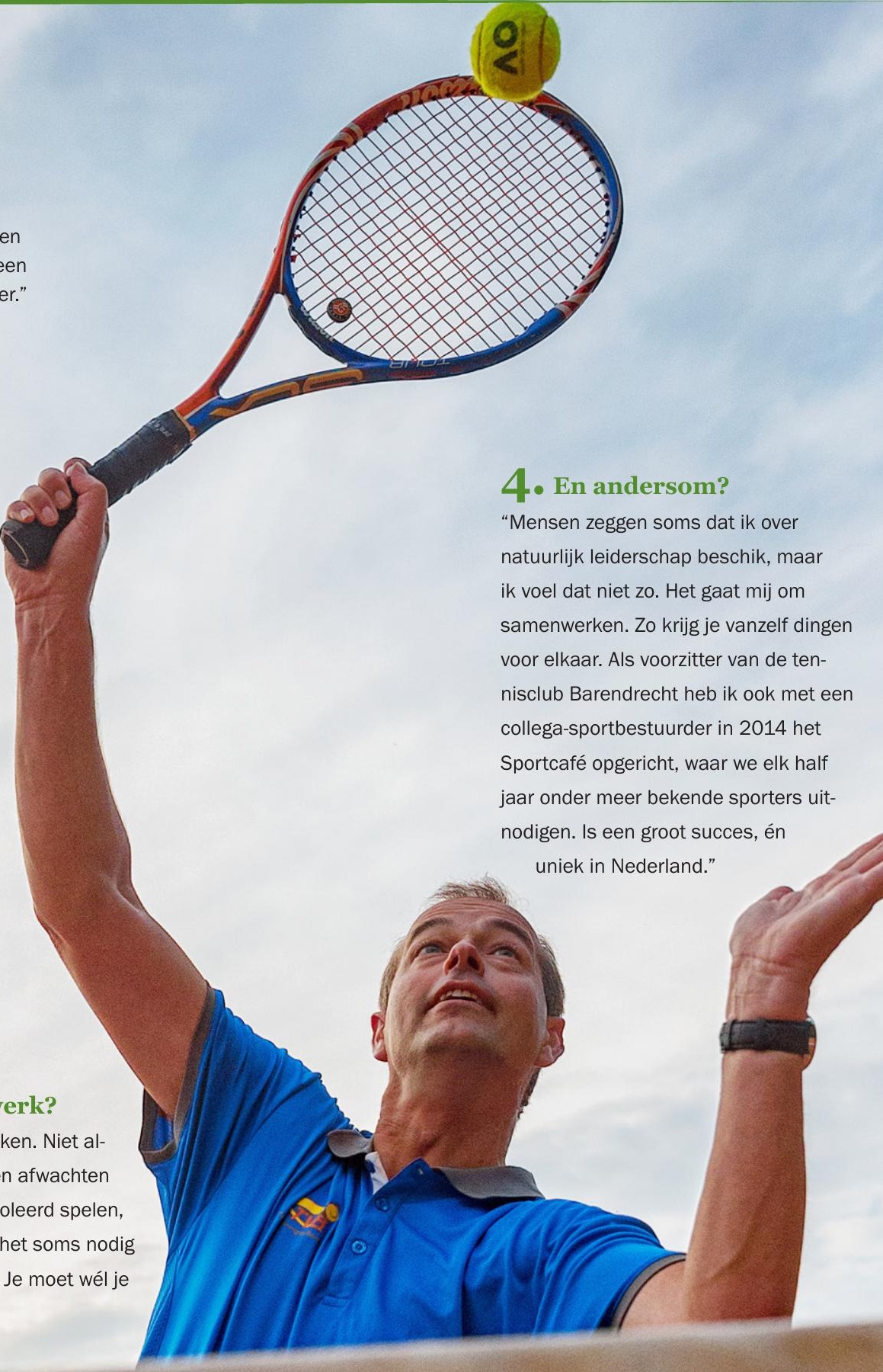

3. Lessen mee naar het werk?

“Niet proberen direct een punt te maken. Niet altijd meteen erbovenop springen. Even afwachten eer je een beslissing neemt. Gecontroleerd spelen, kijken, even taxeren. En natuurlijk is het soms nodig dat je wél meteen actie onderneemt. Je moet wél je 4,2 doel bereiken."

4. En andersom?

“Mensen zeggen soms dat ik over natuurlijk leiderschap beschik, maar ik voel dat niet zo. Het gaat mij om samenwerken. Zo krijg je vanzelf dingen voor elkaar. Als voorzitter van de tennisclub Barendrecht heb ik ook met een collega-sportbestuurder in 2014 het Sportcafé opgericht, waar we elk half jaar onder meer bekende sporters uit, én uniek in Nederland." 